\title{
ЗАЩИТА ТРУДОВЫХ ПРАВ ЖЕНЩИН
}

\section{PROTECTION OF WOMEN'S LABOUR RIGHTS}

\section{Ospichev}

Summary: The article deals with the labour rights of women through the lens of international legislation in the protection of human rights and labour rights of workers. The dynamics of the situation with the protection of women's labor rights in Russia in different historical eras are analyzed.

Several ways are proposed to develop labour legislation in order to ensure that women work equally with men. The external impact on reducing gender inequality is justified. Promising directions for the development of labour legislation in order to protect the labour rights of women in the Russian Federation are being determined.

Keywords: women, gender inequality, labour rights, discrimination, dismissal, international labour organization.

\author{
Оспичев Игорь Михайлович \\ К.ю.н., дочент, ФГБОУВО «Югорский государственный \\ университет», г. Ханты-Мансийск \\ iospichev@yandex.ru
}

Аннотация: В статье рассматриваются трудовые права женщин через призму международного законодательства в сфере защиты прав человека и охраны трудовых прав работников. Анализируется динамика ситуации с охраной трудовых прав женщин в России в разные исторические эпохи.

Предлагается несколько направлений развития трудового законодательства в целях обеспечения женщин на равный с мужчинами труд. 0босновывается внешнее воздействие на снижение гендерного неравенства. Определяются перспективные направления развития трудового законодательства в целях защиты трудовых прав женщин в РФ.

Ключевые слова: женщина, гендерное неравенство, трудовые права, дискриминация, увольнение, международная организация труда.
Д остижение равенства между женщинами и мужчинами и ликвидация всех форм дискриминации в отношении женщин являются основополагающей международных правозащитных организаций. Так, например, с момента основания Организации Объединенных Наций равенство между мужчинами и женщинами было одним из самых фундаментальных гарантий соблюдения прав человека. Принятый в 1945 году устав Организации Объединенных Наций гласит, что организация стремится к развитию уважения к правам человека и основным свободам для всех, без различия расы, пола, языка и религии [1].

Запрет на дискриминацию по признаку пола повторяется во Всеобщей декларации прав человека: «Все люди рождаются свободными и равными в своем достоинстве и правах» [2].

В международных правозащитных организациях, занимающихся вопросами развития, подтверждают, что всестороннее участие женщин в жизни общества является важнейшим фактором экономического развития. Правовые инструменты обеспечения гендерного равенства и защиты прав трудящихся женщин неуклонно совершенствуются как на национальном, так и на международном уровнях, однако, по-прежнему существует разрыв между правами, закрепленными в национальных и международных стандартах, и их реализацией в реальных ситуациях.

Несмотря на то, что женщины составляют жизненно важную часть экономической и социальной структуры, их труд редко оценивается на том же уровне, что и труд мужчин. Женщины чаще мужчин оказываются занятыми на низкооплачиваемой работе и подлежат увольнению за вступление в брак или рождение детей. Во многих отраслях промышленности женщинам систематически отказывают в их правах на регулярную оплату и регулярное рабочее время, равную оплату за равный труд, безопасные условия труда и свободу объединений.

Защита и поощрение прав трудящихся женщин всегда были неотъемлемой частью мандата Международной организации труда (далее - МОТ). Занятость женщин до и после рождения ребенка была предметом одной из первых конвенций МОТ, датируемой 1919 годом [3].

Гендерное неравенство определяется как явление, когда человек подвергается дискриминации или получает неравное обращение в зависимости от своего пола. Это нечто, возникшее из искаженных представлений и социально сконструированных ролей для каждого пола.

На рабочем месте большинство женщин часто сталкиваются с той или иной формой гендерных предубеждений. Эта проблема сохраняется, несмотря на то, что за последние пятьдесят лет женщины добились многочисленных успехов в достижении большего равенства. Кроме того, многие компании также прилагают целенаправленные усилия для поощрения разнообразия и равенства. Но ничто из этого не меняет простого факта, что женщины по-прежнему занимают более низкооплачи- 
ваемые должности и постоянно зарабатывают меньше, чем их коллеги-мужчины.

Женщины продолжают преодолевать гендерные барьеры, и все больше и больше из них выбирают карьеру в традиционно мужских областях, таких как технология и инженерия. И все же, несмотря на все их усилия, женщины по-прежнему получают признание и вознаграждение меньше, чем мужчины. Эта гендерная предвзятость не только несправедлива, но и в конечном счете пагубна для общей корпоративной эффективности.

Эпоха экономических и политических перемен конца XX века в России характеризовалась безработицей, высокими темпами инфляции, исчезающими социальными услугами и надвигающимися угрозами коррупции и организованной преступности. Женщины, в частности, страдали от последствий таких изменений: они сталкивались с широко распространенной дискриминацией в сфере занятости, которая практиковалась и терпимо воспринималась правительством. Дискриминация женщин возникла в результате неуважения россиян к личному пространству и соблюдению норм социального этикета. Возможно, в этом виноваты исторические факторы - крепостное право и советская общинная жизнь.

В настоящее время Россия запрещает женщинам занимать 456 рабочих профессий в десятках отраслей промышленности, связанных с физически напряженными задачами или вредными условиями труда. Вместе с тем, Министерство труда и социальной защиты РФ сократило список запрещенных для женщин рабочих профессий до 98 в рамках реформ, которые должны быть введены в действие в 2021 году. Ограничения по женской занятости содержат рабочие места в подземной добыче полезных ископаемых и строительстве, металлообработке и других отраслях промышленности, которые все еще требуют ручного труда. Согласно новым правилам, женщинам будет разрешено работать водителями грузовиков и машинистами поездов, а также служить в военно-морском флоте. Профессии, требующие тяжелого подъема, такие как сварка, ремонт самолетов или пожаротушение, попрежнему для женщин будут запрещены.

Еще совсем недавно российское трудовое законодательство являлось одним из самых застойных в мире, поскольку женщинам запрещены были сотни профессий. Так, например, в течение пяти лет Светлана Медведева через суд оспаривала свое права на равный труд и доступ к профессии, которая, по мнению работодателя, была «вредной для женщин» [7]. При этом Самарский районный суд удовлетворил иск лишь частично - в требовании заключить трудовой договор истице отказали.

Сегодня в России запрещена любая дискриминация трудовой области, об этом сказано в ст.3 Трудового ко- декса Российской Федерации. В ст. 64 ТК РФ содержится запрет какого бы то ни было прямого или косвенного ограничения прав или установления прямых, или косвенных преимуществ при заключении трудового договора в зависимости от пола, за исключением случаев, предусмотренных федеральным законом, также запрет отказывать в заключении трудового договора женщинам по мотивам, связанным с беременностью или наличием детей [4].

Согласно статистическим данным, например, за 2015 год примерно 30\% всех обращений в Роструд связаны с нарушением трудовых прав женщин (120 000 обращений). Основными причинами заявлений в контрольный орган явились нарушение принципов справедливой оплаты труда (80 000 заявлений), неправильное оформление трудовых договоров (40 000 обращений), прочие нарушения в области охраны труда (6 000 жалоб) [8]. По результатам проверок в прошлом году инспекторы Роструда зафиксировали 3700 действительных нарушений прав женщин в области охраны труда. В процентном соотношении эта цифра невелика - всего лишь $1 \%$ от общего количества нарушений вообще - но по факту это означает около 4 тысяч притесняемых на работе женщин.

Конституционное право распространяется и на мужчин, и на женщин, однако на рабочих местах мы до сих пор имеем случаи гендерного неравенства: за одинаковую работу женщины получают меньшую оплату, кроме того в России женщинам зачастую отказывают в трудоустройстве, опасаясь выхода сотрудницы в декрет и частые отпуска, связанные с необходимостью ухода за ребенком.

По мнению Б.Ж. Тагирова, рациональной причиной всего многообразия проявлений дискриминации женщин на рынке труда является асимметрия информации, порождающая так называемую статистическую дискриминацию, и монопсоническая власть работодателя. Существуют и другие причины дискриминации, не связанные с рациональным выбором, например, мизогиния (личная неприязнь к женщинам) [5, С. 17].

Для устранения такой проблемы необходимо комплексное решение.

Во-первых, законодателю следует учитывать тот факт, что сегодня происходит постепенный отказ от социального стереотипа, согласно которому только женщина должна и может воспитывать детей. Во-первых, судам в целях правильного разрешения споров необходимо учитывать весь объем прав и гарантий, предусмотренных законодательством о труде, а также локальными нормативными правовыми актами нанимателя для работников-женщин, других работников, имеющих семейные обязанности. 
Во-вторых, по мнению А.Ж. Хамзиной женщинам необходимо более активно защищать свои трудовые права, не бояться обращаться в контрольные органы, а государство должно больше времени уделять правовому просвещению граждан в сфере трудового законодательства, защите их прав [6, С. 118].

B-третьих, важно применять международные наработки в области трудового права: активно внедрять новые механизмы регулирования гендерного равенства, продвигать перспективные идеи выравнивания отношения работодателей к труду женщин и мужчин, устанавливать действенные нормы правового регулирования трудового законодательства.

Помимо активного изменения в рамках законодательного регулирования труда женщин сокращению тенденций гендерной дискриминации способствуют пассивные изменения в социально-экономическом плане, в том числе возрастание доли информационного и интеллектуального труда, уменьшение роли традиций в жизни общества, свободный доступ к информации и знаниям, падение рождаемости и удаленная занятость.

Таким образом, гармонизация российского трудового законодательства с международно-правовыми актами в сфере защиты трудовых прав женщин, учет международной правозащитной практики и последних судебных решений в области защиты трудовых прав работников, изменение социально-экономических аспектов жизни общества будут способствовать росту гарантий трудовых прав женщин и соблюдению их интересов в сфере труда.

ЛИТЕРАТУРА

1. Устав ООН [Электронный ресурс] Режим доступа: https://www.un.org/ru/charter-united-nations/.

2. Всеобщая декларация прав человека [Электронный ресурс] Режим доступа: https://www.un.org/ru/documents/decl_conv/declarations/declhr.shtml.

3. Конвенция о труде женщин до и после родов [Электронный ресурс] Режим доступа: http://docs.cntd.ru/document/901875600.

4. Прокопенко А.В. Дискриминация женщин в сфере труда // Молодой ученый. 2016. № 20 (124). С. 559-563.

5. Тагиров Б.Ж. Экономические причины гендерного неравенства на рынке труда // Экономика труда. № 7. (1). С. 15-26.

6. Хамзина А.Ж. Проблема дискриминации женщин в трудовых отношениях // Царскосельские чтения. 2016. С. 116-120.

7. Светлана Медведева: «Суд наконец-то признал факт дискриминации» [Электронный ресурс] Режим доступа: https://www.korabel.ru/news/comments/ svetlana_medvedeva_sud_nakonec-to_priznal_fakt_diskriminacii.html.

8. Ущемление трудовых прав женщин: статистика и факты / [Электронный ресурс] Режим доступа: https://www.centrattek.ru/novosti/1374/.

(c) Оспичев Игорь Михайлович (iospichev@yandex.ru). 